\title{
El humor gráfico español ante el referéndum escocés del 18 de septiembre de 2014 ¿Dibujando la independencia de Cataluña?
}

\author{
Marta ReQueJo FRAILE \\ Universidad de Valladolid \\ marta.requejo.fraile@uva.es \\ Ana María Velasco Molpeceres \\ Universidad de Valladolid \\ anamaria.velasco.molpeceres@uva.es \\ Itziar REGUERO SANZ \\ Universidad de Valladolid \\ itziar.reguero@uva.es
}

Recibido: 24 de febrero de 2016

Aceptado: 12 de abril de 2016

\section{Resumen}

El presente artículo analiza el discurso que los principales diarios españoles dieron al referéndum por la independencia de Escocia, celebrado el 18 de septiembre de 2014, a través del humor gráfico. Mediante el Análisis Textual, el objetivo primordial de este estudio es examinar el tratamiento informativo que realizaron El País, El Mundo, ABC, La Razón, La Vanguardia y El Periódico por medio de sus viñetas de opinión. Esta investigación presenta un campo novedoso de análisis tanto en el tema, abriendo nuevas áreas de trabajo sobre el nacionalismo y el papel de los medios, como en la metodología, pues el examen del humor gráfico continúa siendo una asignatura pendiente en los estudios de comunicación.

Palabras clave: Humor gráfico; nacionalismo; independentismo; Cataluña; Escocia; Prensa

\section{The Spanish graphic humour face with the Scottish referendum of 18th} September 2014: Is it drawing the independence of Catalonia?

\begin{abstract}
This article analyzes the discourse that the main Spanish newspapers gave because of the referendum for the independence of Scotland (18 of September 2014), through the graphic humor. By means of textual analysis, the chief objective of the article is to examine the informative treatment that El Pais, El Mundo, ABC, La Razón, La Vanguardia and El Periódico did through their opinion vignettes. The research introduces a new field of thematic focus, opening areas of working on nationalism and media, as well as in methodology, because the research of graphic humor remains an unresolved matter in communication studies.
\end{abstract}

Keywords: Graphic humour; Nationalism; Independence; Catalonia; Scotland; Press 


\section{Referencia normalizada}

Requejo Fraile, M., Velasco Molpeceres, A.M. y Reguero Sanz, I. (2016). El humor gráfico español ante el referéndum escocés del 18 de septiembre de 2014. ¿Dibujando la independencia de Cataluña? Historia y Comunicación Social. Vol 21, número 1, páginas 15-37.

Sumario: 1. Introducción. 2. Metodología. 3. Crítica al independentismo como corriente política y social. 4. El mito colectivo: el "Monstruo" del nacionalismo escocés. 5. Influencia de Escocia en España y en Europa. 6. Preocupación ante las consecuencias del resultado. 7. La integración de los estados en democracia. 8. El Periódico de Cataluña: una excepción en el tratamiento del 18-S. 9. Conclusiones. 10. Referencias bibliográficas.

\section{Introducción}

La influencia del humor gráfico en la creación de climas de opinión ha sido estudiada en España desde hace más de un siglo. Ya en 1878 y 1892 encontramos referencias en esta área de investigación gracias a los trabajos de Octavio Jacinto Picón y F. Tomás Estruch sobre la historia de la caricatura en el periodismo español. En el siglo XX, esta línea continúa de la mano de José Francés quien, desde 1915, con La caricatura española contemporánea, se dedicó al análisis de la situación e influencia del humor gráfico. Así, es necesario destacar que en estos años no se entenderá el discurso político sin hacer referencia a su plasmación en imágenes (Martínez et al., 2008). Por ello, surgen una gran cantidad de autores que, a partir de ese momento, decidirán enfocar sus análisis en esta línea de estudio. Sin embargo, es reseñable que, pese a ser objeto de un prolífico análisis, estas investigaciones adolecerán de una adecuada definición conceptual así como metodológica, al menos, en la mayor parte de los casos (Meléndez, 2005).

El concepto de humor gráfico ha sido, por lo general, un vocablo abordado con herramientas alejadas de la ortodoxia científica (Barrero, 2008). Este fenómeno se ha dado hasta tal punto que a día de hoy sigue existiendo una escasa univocidad en su descripción. En el ámbito de la prensa escrita, ha sido considerado, en líneas generales, como un tipo de género más propio de las páginas de opinión que del mundo informativo. Mientras que, en la Academia, los autores han optado por el empleo de las expresiones "dibujo satírico", "chiste gráfico" o "caricatura" haciendo del concepto "humor gráfico" una noción en desuso. No será hasta comienzos del siglo XXI, cuando de la mano de José Antonio Llera (2003: 90) asistamos a una revitalización del mismo. Para este autor se trata en definitiva de "una potencial suma interactiva de signos verbales y signos icónicos en régimen de coexistencia dentro del espacio simbólico de la viñeta", es decir, de un tipo de género periodístico que, mediante la combinación de códigos visuales y lingüísticos, representa, interpreta y contextualiza un determinado mensaje en tono jocoso. Desde este punto de vista compartimos la opinión de Carlos Abreu (2000) cuando indica que las expresiones anteriores no son más que subgéneros o "ramificaciones" de la definición de humor gráfico anteriormente mencionada. 
En cuanto a las líneas de trabajo desarrolladas, cabe mencionar que son raras las investigaciones empíricas en las que se puede encontrar la aplicación de un adecuado método de análisis. Si bien éstas han estado más enfocadas hacia una perspectiva histórico-documental. De entre todas ellas, destaca, sobre todo, la centrada en la prensa satírica durante el Franquismo y la Transición (Hernández, 2001; Moreiro \& Prieto, 2001; Peñamarín, 2002; Llera, 2003; Segado, 2008, 2009, 2012, VV.AA, 2013). Como señala Luis Carandell (1992: 10), "en todos los periódicos del mundo se publican chistes" "entendiendo chiste como humor gráfico" pero es en España, por su tradición política y el esplendor del humor gráfico en la Transición, cuando estas ilustraciones "adquieren el rango de un editorial del periódico". Esto explica la importancia de las viñetas y de su estudio pues, como aclara Manuel Piedrahita (1986: 3), tienen "en muchos casos, mayor captación que un editorial". Opinión compartida por el inglés Fraser Bond (1974), quien ve en las viñetas un modo de exposición del punto de vista del periódico de forma gráfica.

A comienzos de los 70, Chumy Chúmez -humorista gráfico- insistía en que "la evolución del humor español ha sido el reflejo de la realidad española, entendiendo por realidad no solamente lo que ocurría, sino también las fuerzas que hacían que se conociesen solo algunos aspectos de esa realidad" (Segado, 2009: 18). Desde entonces el humor gráfico se ha ido instalando en numerosas publicaciones hasta llegar a ocupar un lugar privilegiado en las páginas en la actualidad. Tal y como indica Laguna (2003: 127), este tipo de género "posee la fuerza de la imagen, la riqueza de la imaginación y la capacidad de la provocación". Además, su efecto social "podrá ser tan subversivo o más que el texto. Primero por su capacidad de llegar a más gente, habida cuenta de la facilidad de lectura que tiene la imagen y, sobre todo, por la dificultad intrínseca de valorar la carga crítica del dibujo" (Laguna, 2003:128). El atentado contra el semanario francés Charlie Hebdo o la polémica suscitada en 2005 en torno a las caricaturas de Mahoma en el diario danés Jillands Posten son solo algunos ejemplos que ponen de manifiesto la importancia de esta afirmación. A este respecto, estamos de acuerdo con Meléndez (2005: 12) cuando indica que el humor gráfico "es un elemento más entre los posibles discursos que contribuyen al asentamiento o al cambio de valores sociales".

Conscientes de ello y dada la importancia que la cuestión separatista ha alcanzado tanto dentro como fuera de nuestras fronteras en la última década, decidimos estudiar el modo en que las principales cabeceras de la prensa diaria española representaron en sus viñetas el referéndum celebrado por la independencia de Escocia el 18 de septiembre de 2014. En este sentido, no podemos olvidar que durante esos días este tema fue una de las principales preocupaciones de la agenda política de la Unión Europea, al tiempo que dio lugar a una amplia cobertura mediática en el territorio español por la repercusión que sus resultados pudieran tener sobre la consulta soberanista catalana el 9 de noviembre de 2014.

Para efectuar este análisis, los objetivos de los que partimos se concretaron en los siguientes: 
- Analizar el discurso que a través de sus viñetas transmitieron El País, El Mundo, ABC, La Razón, La Vanguardia y El Periódico sobre la cuestión separatista escocesa en particular y sobre el nacionalismo en general.

- Determinar los principales ejes temáticos en los que se basaron estos diarios para la construcción de sus mensajes.

- Estudiar la identificación que se establece en los seis periódicos entre la cuestión escocesa y la consulta de Cataluña por medio del humor gráfico.

- Dictaminar la principal línea editorial que la 'opinión publicada', a través de este género, trató de hacer llegar a la opinión pública.

Todo ello con el fin de verificar o refutar la siguiente hipótesis de partida: la prensa española empleó el referéndum por la independencia de Escocia como hilo argumental para deslegitimar o aprobar la situación que dos meses después viviría España con Cataluña durante la consulta del 9-N.

\section{Metodología}

Con el fin de alcanzar los objetivos planteados, esta investigación ha sido realizada aplicando la Teoría del Texto o Análisis Textual -desarrollada por el catedrático de Comunicación Audiovisual de la Universidad Complutense de Madrid, Jesús González Requena (1996)- en las diferentes viñetas publicadas en las páginas de El País, El Mundo, ABC, La Vanguardia, El Periódico y La Razón ${ }^{I}$ entre los días 1 y 21 de septiembre de 2014.

Estas fechas fueron escogidas para estudiar la permanencia y los cambios de los discursos de los diferentes medios sobre el referéndum escocés y la consulta catalana, dado que ambos procesos se solaparon en el tiempo. El 18 de septiembre se celebró la votación escocesa y el 19 -simbólicamente refrendando el "sí" escocés, que resultó en 'no'- se aprobó la ley de consultas (Ley 10/2014). Por ello, para analizar la visión que los medios trasladaban sobre estas cuestiones, consideramos necesario seleccionar desde el comienzo del proceso hasta su fin.

La Teoría del Texto parte del "giro lingüístico", como lo llamó Richard Rorty (1990), que define la posmodernidad situando el lenguaje en primacía sobre la realidad. Se considera así que lo lingüístico deja de ser un medio válido y útil para representar la realidad externa a ello, o para relacionarse con el mundo -que ya no es una entidad distinta al lenguaje-, y que se transforma en un agente constructor de mundos: la realidad puede cambiarse por el lenguaje, desde el interior, sin estar predeterminada.

Por tanto, se eleva "lo poético", la experiencia estética, a forma de conocimiento y se considera que el método científico está limitado en tanto que no puede salir del lenguaje; como dice Nietzsche, el hombre está atrapado en la jaula del lenguaje. A consecuencia 
de esto, el objeto de estudio ya no es la realidad sino el símbolo: el texto -que es tanto la palabra escrita (al fin y al cabo, es icónica en tanto que tiene grafía), como la imagen-.

El gran artífice de este cambio de pensamiento es Foucault quien plantea que el lenguaje es el inicio del pensar y, partiendo de Nietzsche (1979), explica que como el lenguaje es signo -y puede reducirse a una metáfora- no sirve para acceder a la realidad: es una máscara de lo que se expone, el vehículo de un engaño. Como señala Umberto Eco (2000), lo que diferencia el significante humano de la señal animal es que esta está obligada a ser siempre verdadera, mientras que el lenguaje sirve para mentir.

De esta manera, lo que interesa a Requena es la dimensión simbólica del lenguaje, es decir, la verdad vinculada a la experiencia subjetiva ante lo "real" -en tanto que ya no existe "la-cosa-en-sí" sino "la-cosa-para-mí", como señalaba Kant (1990)- pues considera que no hay más que categorías abstractas, nuevos signos, que remiten a otros signos y que no hay más hechos que los del lenguaje.

Así, el Análisis Textual consiste en el deletreo del texto objeto de estudio. Se narra lo que aparece en el mismo, transmitiéndose la información que llega al receptor. No solo lo que el autor pretende trasladar, lo cual sería objeto de interpretación, sino lo que recibe el destinatario de esos textos. Esto es especialmente valioso en el estudio del humor gráfico pues, como Rorty apunta, un problema del mundo contemporáneo es la sumisión del lenguaje a lo políticamente correcto y la caída de la cultura occidental en un relativismo, que considera pernicioso (1990). Precisamente, la caricatura se libra de este lastre porque no hay riesgo de que lo dibujado suplante a lo 'real' y, por ello, se le permite llegar más lejos de lo que una publicación iría en sus contenidos escritos, en las fotografías elegidas $\mathrm{e}$, incluso, en su editorial.

De este modo, el uso del Análisis Textual para el estudio del humor gráfico publicado en España sobre el referéndum escocés es interesante porque se aparta de la ideología y se centra en la pieza objeto de investigación que, en tanto que ilustración, puede ser grotesca y mucho más agresiva -y por ello más elocuente- que el resto de elementos del periódico.

Se trata, pues, de un trabajo de tipo cualitativo, en el que se procede al deletreo de las imágenes, a la narración "descarnada", de lo que se ve en las viñetas. Hemos descartado la comparación cuantitativa en cifras de cada medio dado que el número de unidades de humor gráfico en publicaciones no satíricas no es muy alto y porque esos datos están muy lejos de la profundidad que pretendemos con este análisis, así como de la finalidad del mismo.

\section{Crítica al independentismo como corriente política y social}

La descalificación a la posible independencia de Escocia y, por extensión, al separatismo catalán ha sido uno de los temas más tratados por los humoristas gráficos españoles en los diarios La Razón, ABC y El País. Bien con banderas como telón de fondo o por medio de la representación de barcos 'saboteados' o 'a la deriva', los 
dibujantes no han dejado de incorporar este elemento a sus análisis a lo largo de los veintiún días que han compuesto la muestra del estudio. La crítica de todos ellos, salvo excepciones, ha partido del mismo punto: el nacionalismo es un movimiento recurrente que siempre actúa de manera interesada. Así lo pone de manifiesto El Roto en su viñeta en El País el día 10 de septiembre.

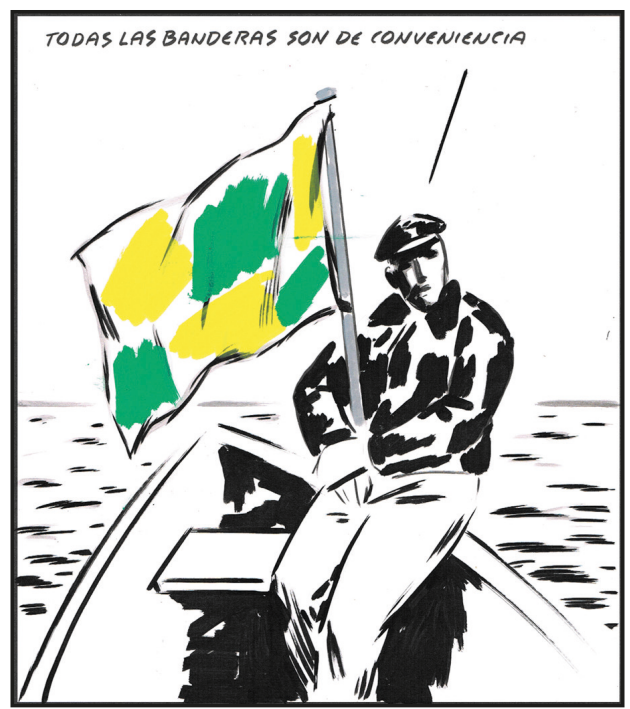

Con esta imagen ${ }^{2}$, y sin señalar a nadie en particular, El Roto hace un guiño a los numerosos secesionismos activos en Europa, identificándolos con un barco perdido, que navega sin rumbo, con la única ayuda de una bandera (elemento identificativo en la representación de regiones o países por excelencia). "Todas las banderas son de conveniencia" reza el texto y el humorista deja entrever, con esa frase, que los motivos del secesionismo no son tan puros: se enarbolan según tocan. También transmite que ningún nacionalismo tiene la solución a los problemas, pues aparece cuando la situación es ventajosa para ellos; $y$, al tiempo, explica que no llevan a ningún lado: el nacionalista es el náufrago a la deriva.

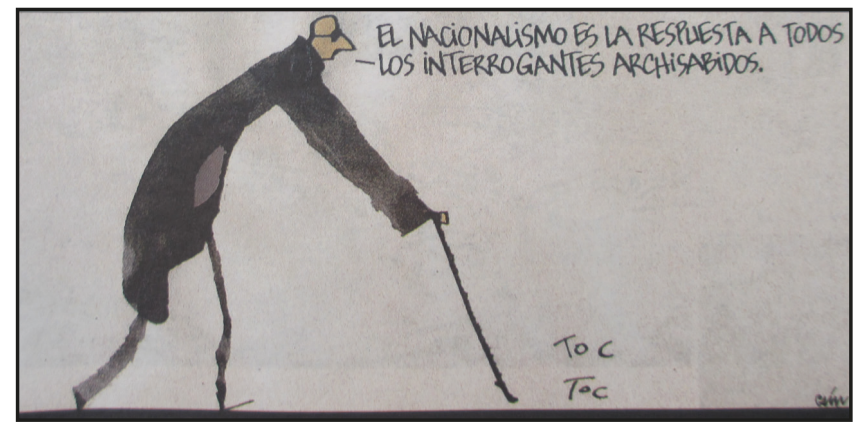

Con el mismo leitmotiv, está concebida la viñeta ${ }^{3}$ del 8 de septiembre de Caín en La Razón. El humorista habla del nacionalismo como un mal recurrente de la historia ante las situaciones adversas. El independentismo aparece representado como una cuestión que se trae a colación cuando las cosas marchan mal, de forma continua en la historia, y repitiendo en todos los momentos el mismo argumento. Valiéndose de un anciano -figura que tradicionalmente se asocia a la experiencia, la sabiduría y el paso del tiempo-, Caín reflexiona sobre lo vano del nacionalismo y critica a todos los que, gracias a él, prometen la superación de los distintos problemas con un discurso obsoleto y $\sin$ recorrido. 


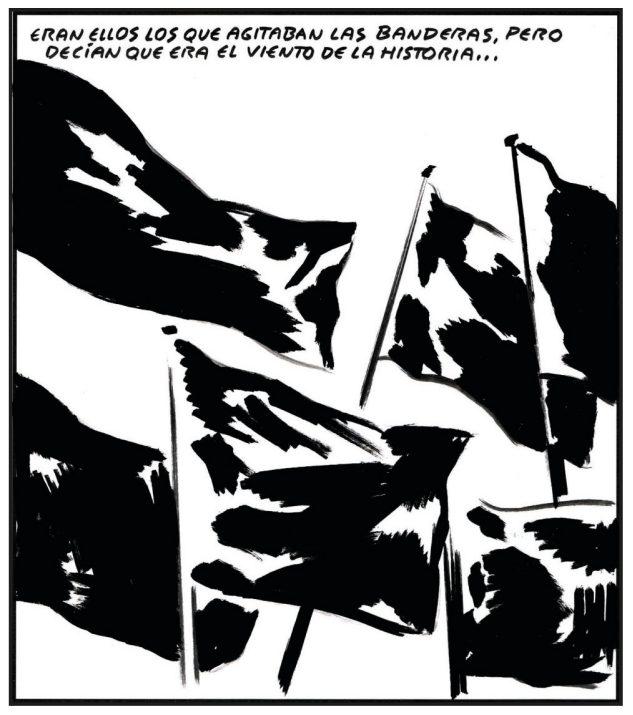

Igual que en la viñeta del día 10, El Roto, en El País el 19 de septiembre ${ }^{4}$, vuelve a usar el recurso de las banderas para criticar el secesionismo. Dibuja varias telas ondeando al viento y con la leyenda "eran ellos los que agitaban las banderas, pero decían que era el viento de la historia", ataca al nacionalismo aludiendo a dos de sus argumentos: el bagaje histórico del territorio en cuestión y, a su vez, el sentimiento popular como justificación de las actuales reclamaciones independentistas. Así, concluye que esa "historia" que se esgrime como fuerza no es más que una manipulación, pues no es el 'viento' o la corriente popular la que causa el nacionalismo, sino los subterfugios de unos pocos -los que enarbolan esas banderas-.

Con los resultados sobre la mesa y sin dejar de lado el simbolismo de la bandera,

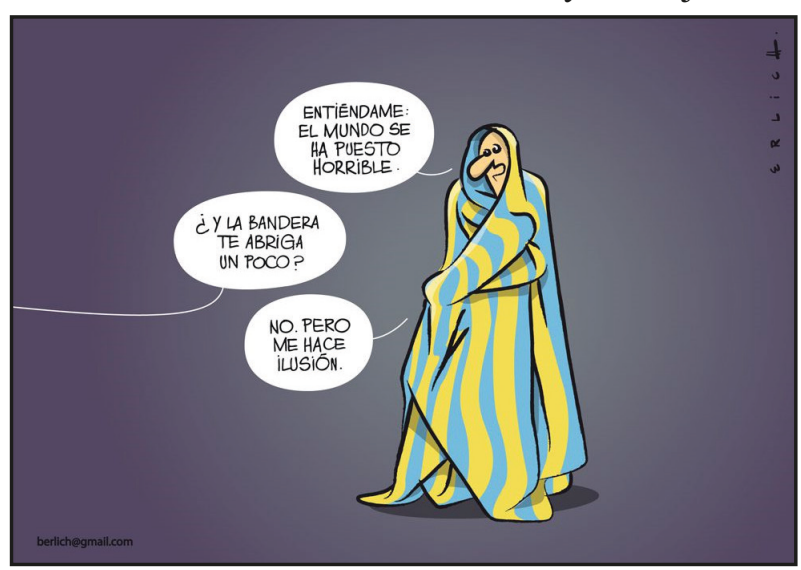

El País continúa su crítica a los movimientos nacionalistas el día 21 de septiembre. Para sustentar esta opinión Erlich muestra en su viñeta ${ }^{5}$ a un hombre envuelto en una bandera a modo de escudo contra los males de la sociedad. Cabe señalar que esta tela es de rayas amarillas y azules (colores presentes, por separado, en la bandera catalana y escocesa) y que se parece a la señera. Alguien pregunta por la utilidad de la bandera como defensa ante el devenir del mundo (que "se ha puesto horrible") y él responde que no le protege pero que le "hace ilusión". Esto es una crítica al nacionalismo pues Erlich lo ve inoperante como solución de los problemas y retrata a sus seguidores como infantiles, que solamente se suman a esa tendencia populista por estar de moda, "por ilusión", aunque, en el fondo, saben de su inutilidad.

En La Razón del 20 de septiembre, Caín, con una viñeta ${ }^{6}$ de gran abstracción y geometría, ataca al nacionalismo criticando que sus seguidores son adeptos populistas y no personas con verdaderas convicciones. Dos partidarios del sí ("yes!!" se lee en el estandarte que portan) aseguran que han "perdido las ideas" pero que 


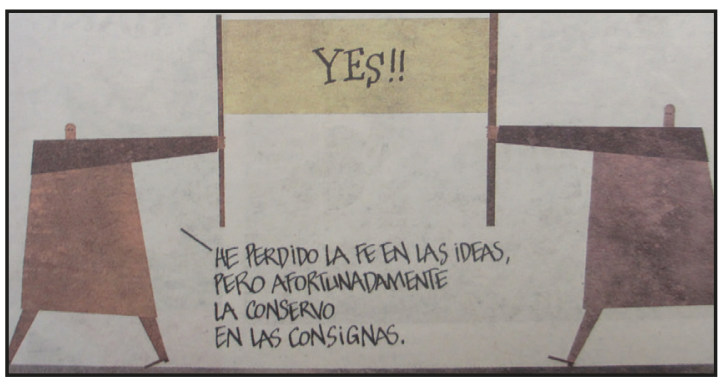
del que hablaba Ortega pues la fuerza de esa misma corriente va ganando terreno a la reflexión y la crítica.

El 15 de septiembre, JM Nieto en $A B C$ vuelve a incidir en la vacuidad del naciona-

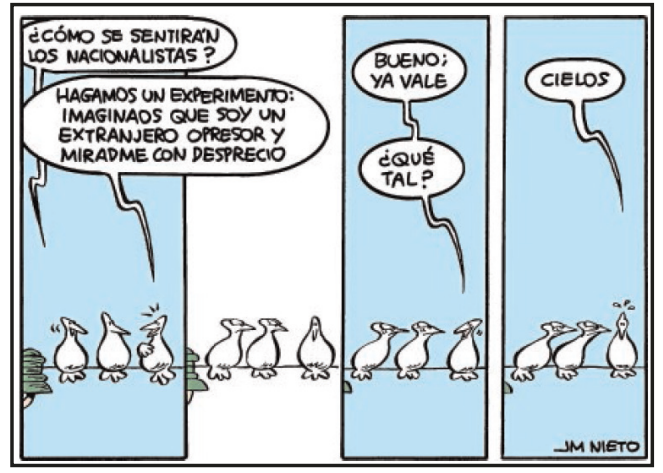

lismo ${ }^{7}$. Una bandada de pájaros posada en un cable reflexiona sobre el tema preguntándose cómo se sentirán los nacionalistas. Para aclararlo, uno de los pájaros -idéntico a los otros- propone hacer un experimento: "imaginaos que soy un extranjero opresor [metáfora de España respecto a Cataluña] y miradme con desprecio". Los otros lo hacen y él acaba sintiéndose incómodo y les pide parar. No lo hacen, sino que redoblan sus esfuerzos, y el pájaro excluido interpela al espectador y dice "cielos" con cara de estupor. Esta crítica al nacionalismo se basa no solo en la igualdad de condición de los pájaros -el extranjero opresor y los nacionalistas son iguales- sino que

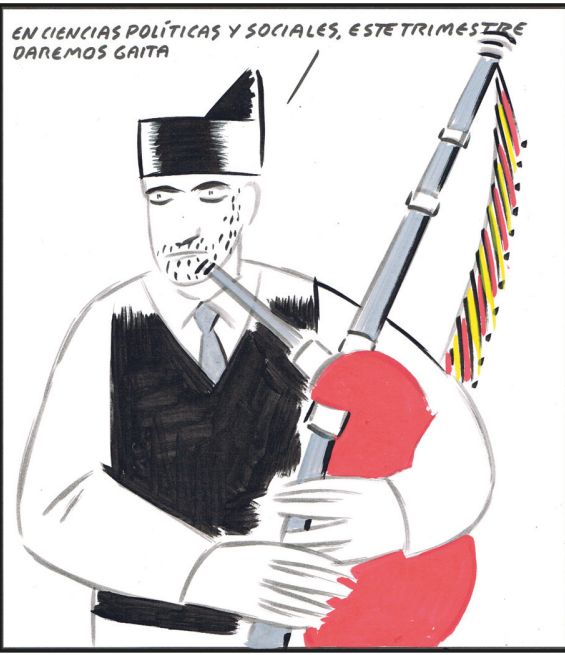
también se centra en la idea de que no son los secesionistas las víctimas de los centralistas sino el Estado central el que es, precisamente, oprimido con las reivindicaciones de los nacionalistas pese a que la actividad era una ficción, "un experimento" que, una vez iniciado, son los secesionistas los que lo llevan más lejos.

La viñeta ${ }^{8}$ de El Roto, en El País el 9 de septiembre, ataca a los movimientos separatistas, así como a sus consecuencias. Mediante la representación de un hombre tocando la gaita (instrumento típico de la región escocesa) con los colores de la 
bandera catalana, el dibujante pone de manifiesto cómo Cataluña seguirá -al son de la música- los pasos dados entre Reino Unido y Escocia durante los siguientes tres meses para avanzar en su carrera hacia la consulta catalana del 9-N. Así se señala en el texto en el que se apoya la imagen: "en ciencias políticas y sociales, este trimestre daremos gaita", es decir, actuaremos conforme lo haga Escocia. Con el simbolismo de este instrumento, y la crítica de la propia frase ("Tocar la gaita"), El Roto reprocha no solo el ruido absurdo que lo está tapando todo, sino lo vacuo del debate político sobre esa cuestión en el país.

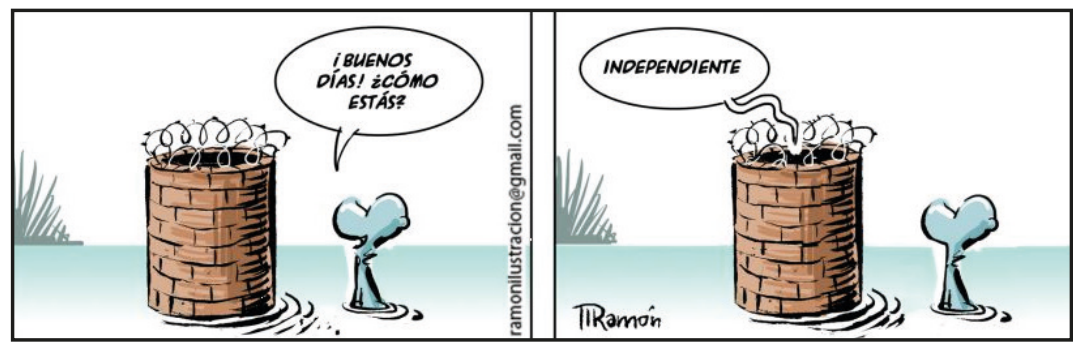

El 12 de septiembre, Ramón ${ }^{9}$ en El País refleja la conversación mantenida entre un hipopótamo y alguien situado en el interior de una torre fortificada. El individuo que acaba de llegar a la torre -que representa al Estado central- pregunta al que está dentro con gran amabilidad por cómo está y le desea buenos días. La respuesta le deja sorprendido: solo recibe un "independiente" a modo de explicación. La viñeta critica a los nacionalistas, quienes, sin mediar motivo para desear tal independencia ni para fortificarse ante este personaje que les saluda amablemente y les trata con afecto y preocupación, adoptan una situación de inmovilismo y antidiálogo, así como de militarismo y populismo, que Ramón ve sin sentido.

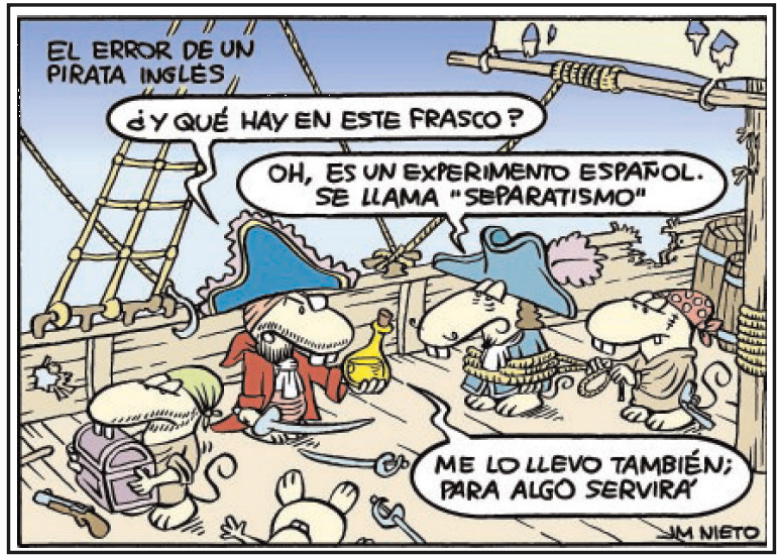

Igual de crítico se muestra JM Nieto ${ }^{10}$ el 14 de septiembre en $A B C$. Interpreta el autor al nacionalismo como una pócima secreta y peligrosa (pues aparece presentada en un frasco cerrado) a la que, por el momento, atribuye poco rédito. Pese a no saber muy bien de qué se trata, el pirata decide llevársela diciendo que "para algo servirá". Nieto critica la falta de pureza de los nacionalistas que usan este concepto, sin saber muy bien a qué se refiere, para sacar ventaja en las diferentes situaciones. Los descalificativos al separatismo y a su escasa fiabilidad también se dejan sentir mediante el empleo de la palabra 'experimento' para referirse al mismo. 


\section{El mito colectivo: el "Monstruo" del nacionalismo escocés}

En algunos de los diarios objeto de estudio, además de criticar el separatismo como fenómeno social (ver bloque anterior), los humoristas gráficos han representado particularmente el nacionalismo de Escocia como algo inventado, sin rigor ni importancia. Para plasmar esta idea, los dibujantes de La Razón, ABC y El Mundo han identificado esta conciencia nacional con el monstruo del lago Ness: siempre se ha puesto en duda la veracidad -y en consecuencia la credibilidad- de la historia que rodea a esta criatura legendaria. Suele decirse que Nessie en realidad no es más que un reclamo para favorecer el turismo en Escocia y que su existencia solamente beneficia a los intereses de la población local. Este aspecto podría extrapolarse con la percepción que ciertos diarios tienen del separatismo escocés.

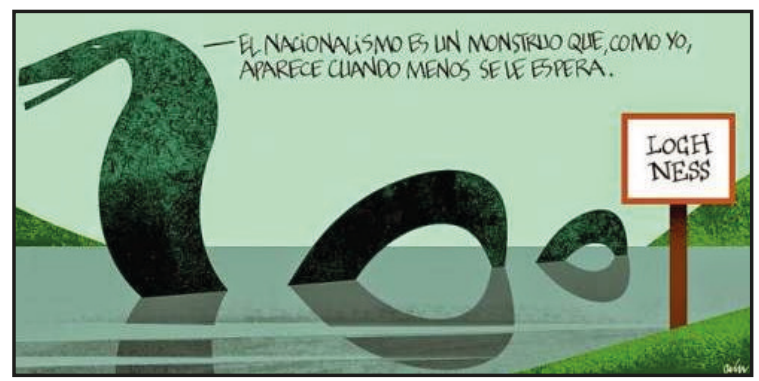

En La Razón, el día del referéndum, Caín ilustra ${ }^{11}$ a Nessie en el lago exclamando: "el nacionalismo es un monstruo que, como yo, aparece cuando menos se le espera". Se percibe que el dibujante trata al separatismo escocés con un matiz negativo: lo considera "un monstruo" impredecible, que brota en la sociedad en determinados momentos de cambio e inestabilidad, pero que no está imbricado en la vida de los escoceses. Es, por ello, una cuestión que se saca a relucir de vez en cuando, para beneficiar a un grupo de personas, pero que no va más allá de esas apariciones pasajeras pues, como Nessie, sus avistamientos no tienen una base real.

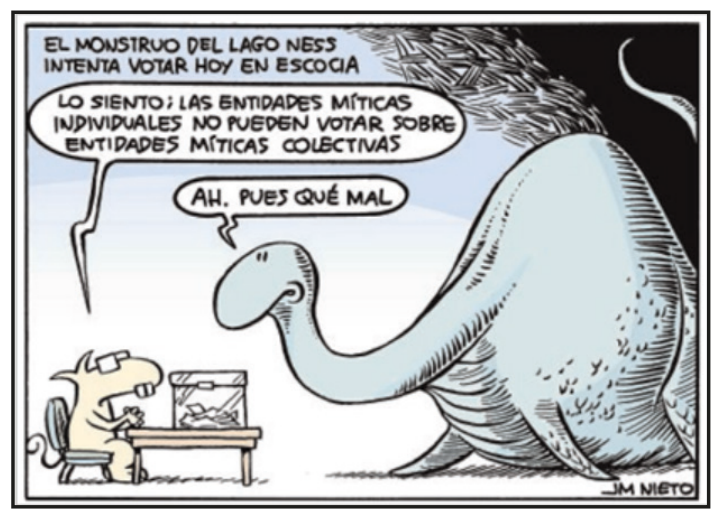

En la fecha de la votación (18-S), Nieto en $A B C$ dibuja ${ }^{12}$ a Nessie tratando de depositar su voto en el referéndum por la independencia de Escocia. El personaje que está custodiando la urna no deja participar al monstruo, alegando que "las entidades míticas individuales (el monstruo) no pueden votar sobre las entidades míticas colectivas (el nacionalismo escocés)". El dibujante, al igual que en el caso anterior, trata de plasmar que, tanto el nacionalismo como la criatura legendaria, son totalmente ficticios y por ello considera que ambos aspectos no deben interferir en la realidad del pueblo escocés. Lo único que los diferencia es que el monstruo es 
un ser individual, mientras que el separatismo es una conciencia colectiva: un mito mucho mayor mantenido por más crédulos aunque, no por ello, más real.

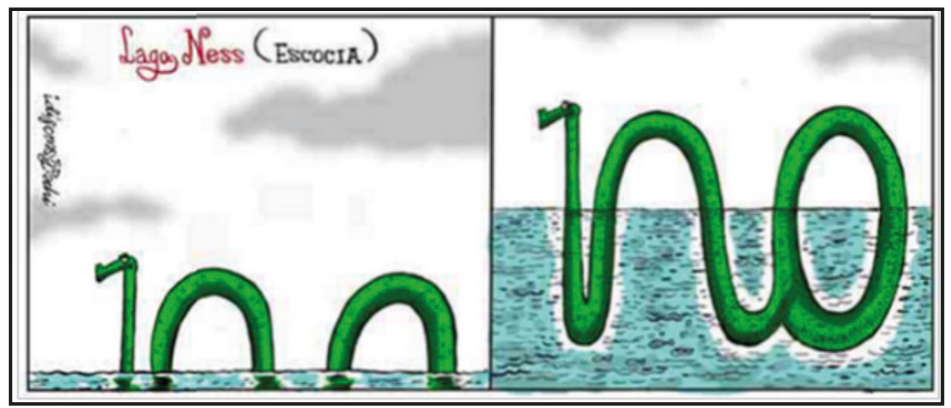

El 20 de septiembre, El Mundo representa el desenlace de la votación a través del mítico monstruo. La viñeta ${ }^{13}$ de Idígoras y Pachi se divide en dos partes: en la primera, Nessie está navegando en el lago pero, en la

segunda, como si fuera un iceberg, vemos que el cuerpo completo del monstruo delinea con su figura un 'no'. El mensaje que se obtiene de unir las dos partes es claro: el nacionalismo escocés, si solo exhibe una parte de sus efectos, tiene una apariencia 'distorsionada' respecto a cómo es en realidad: no es más que un mito pues, si nos sumergimos en el trasfondo de la cuestión y vemos el panorama en su totalidad, el 'no' a la independencia es lo que se haya oculto.

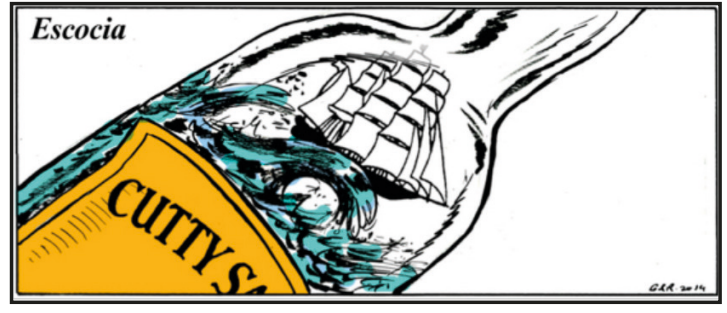

Asimismo, dos viñetas representan las consecuencias adversas que acarrearía un hipotético 'sí' en el referéndum del 18-S, tanto para Gran Bretaña, como para Escocia. El Mundo publica una ilustración ${ }^{14}$ donde, en una botella del whisky escocés Cutty Sark, aparece un barco atrapado en un mar embravecido donde las olas parecen conducir a la embarcación hasta el naufragio. El navío representa al nacionalismo en Escocia que, enclaustrado en la idea del separatismo (la botella), no tendrá cómo salir de la difícil situación en la que se ha sumido al convocar el referéndum.

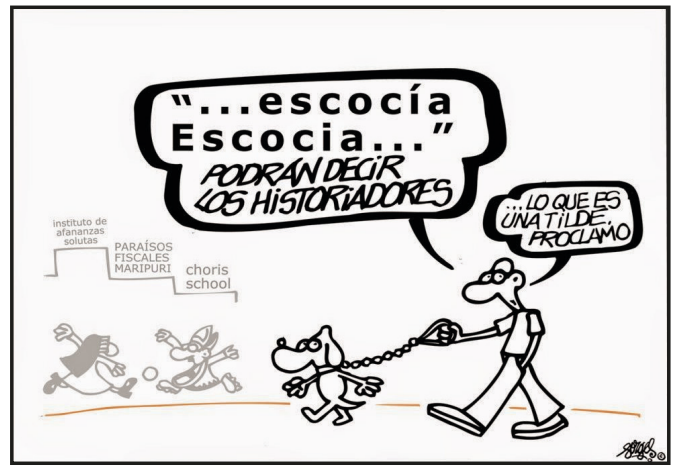

En otra viñeta ${ }^{15}$ de Forges se trata sobre las repercusiones que podría acarrear la independencia del territorio escocés. En la imagen publicada en El País, el 17 de septiembre, aparece un viandante con su perro pensando: ““...escocía Escocia...' podrán decir los historiadores... Lo que es una tilde, proclamo". Parece que el hombre augura que Escocia se convertirá en la cuna de los paraísos fiscales y que es 
el desvío de fondos lo que 'escocería' las finanzas, tanto inglesas como escocesas, como se puede leer en los edificios que aparecen al fondo de la viñeta (Instituto de "afananzas solutas", Paraísos fiscales "Maripuri" y "choris school").

\section{Influencia de Escocia en España y en Europa}

El ejemplo del caso escocés, tanto en España como en el Viejo Continente, ha sido otro de los temas que más ha preocupado a los dibujantes españoles. Las diferentes cabeceras han estudiado las consecuencias del referéndum independentista y también el contagio de este secesionismo en los nacionalismos europeos. Igualmente, se han interesado por su repercusión en la unidad del continente -especialmente en lo relativo a la situación de la Unión Europea ante estas posibles rupturas internas y, en todo caso, en lo tocante al trauma de la amenaza de su desmembramiento-.

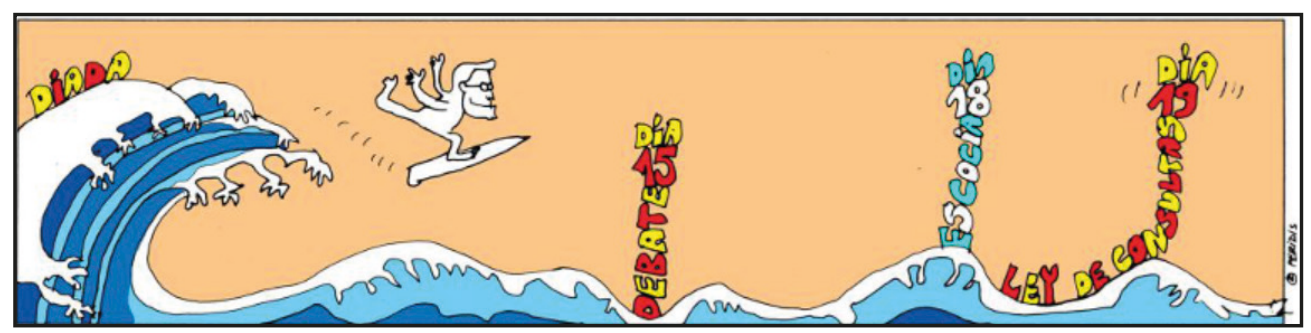

Peridis, en El País del 14 de septiembre de 2014, dibuja ${ }^{16}$ a Artur Mas como un surfista intrépido que salta de ola en ola, esperando no caer. El impulso de la Diada le ha lanzado a una carrera contrarreloj y desesperada en la que puede, como en el surf, quedar parado, sin la ayuda de la corriente. Mas espera llegar a la independencia arrastrado, en este caso, por un viento que no es tan proclive como parece. El debate del día 15 de septiembre y, especialmente, la aprobación o no de la Ley de Consultas del día 19, son sus grandes escollos. La independencia de Escocia, a resolver en el referéndum del 18, puede darle un impulso o todo lo contrario. Demasiados obstáculos por sortear y demasiada efervescencia e inconsciencia de un Mas que se apoya -se 'apoya'- en la deriva de la corriente, o sea, en nada.

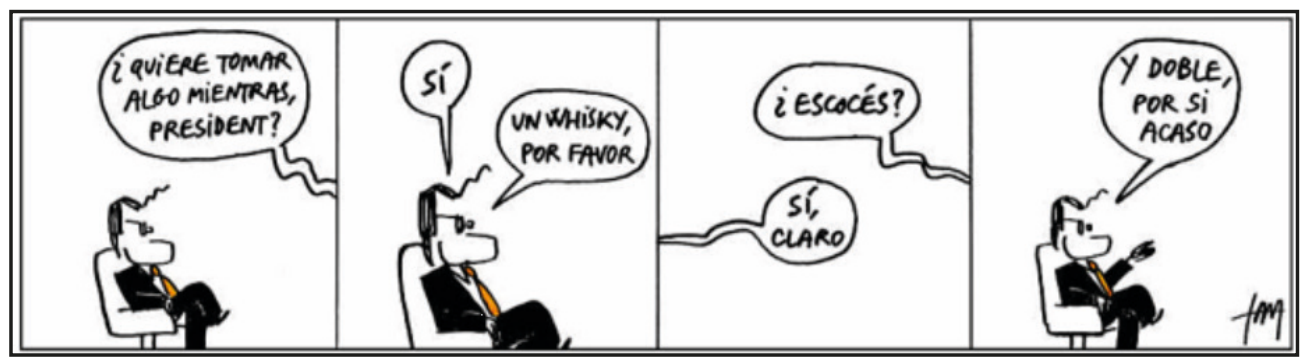


Igual de temerario dibuja Toni Batllori a Artur Mas en su tira cómica ${ }^{17}$, titulada Ninnots, de La Vanguardia el 19 de septiembre de 2014. En ella, sentado en una silla esperando -se sobreentiende que a los resultados de Escocia- recibe el ofrecimiento de una bebida. Pide un "whisky" y, ante la pregunta de si "escocés", afirma que "sí, claro" y añade "y doble, por si acaso". La idea de dejarse llevar por la corriente del referéndum escocés para la independencia de Cataluña es clara. También el desdén o la chulería de este Artur Mas que, ante la magnitud del reto en el que se encuentra -la construcción de un nuevo estado, la separación de España, la división interna y la oposición del gobierno central- no está trabajando en su proyecto sino impertérrito, como un jugador ante la ruleta: esperando que la bola caiga, donde la lleve el viento, la corriente, el azar... y le haga ganador de lo que ha sido únicamente una apuesta. Una jugada muy peligrosa y muy vana pues, ante lo que le sobreviene, solo sabe esperar y redoblar su apuesta.

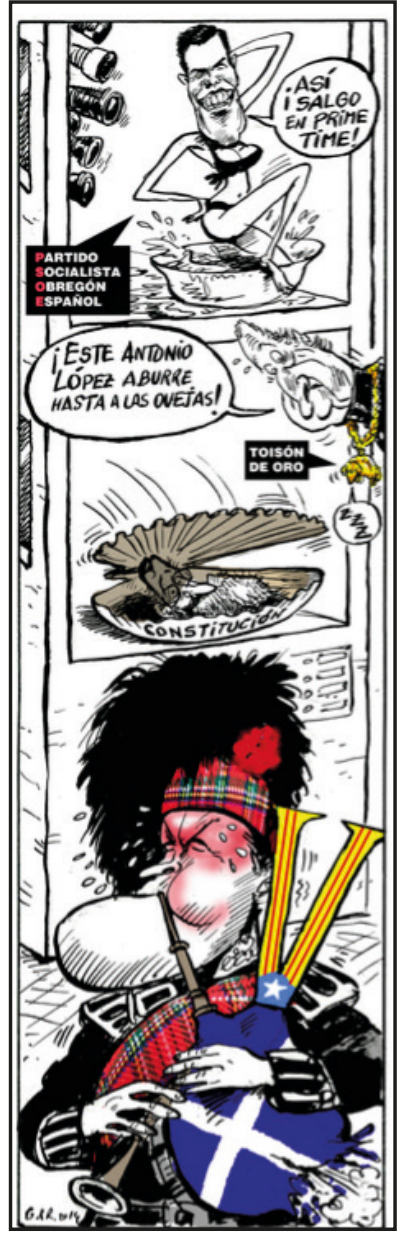

Frente a este Mas que se cree ganador en su apuesta de vincular Escocia y Cataluña, en El Mundo del 20 de septiembre de 2014, tenemos esta viñeta ${ }^{18}$ que le retrata como a un gaitero escocés, vestido con el tartán y la bandera, así como con la señera catalana -que forma la V de la Diada-, ahogándose con la gaita: la música no suena como quería y el 'no' a la independencia ha ganado el referéndum escocés. Ahora, el símil Escocia-Cataluña se le atraganta y le ahoga. Eso sí, la situación del país no es mejor. Mas puede estar asfixiándose pero el ruido que está haciendo, por desagradable que sea, está afectando al Estado. La inestabilidad ha llegado a esta comunidad de vecinos que aparece publicada en El Mundo cada sábado: Rajoy está como el avestruz, guardando la cabeza bajo el ala -en este caso, bajo la Constitución- como si enarbolar, y no con mucho brío, esa carta le fuera a hacer ganar una partida que tiene perdida de antemano.

La oposición, Pedro Sánchez, vive de exhibirse, no resguardado como Rajoy. Dibujado esperpénticamente con cuerpo de modelo de catálogo de bañadores femeninos, su figura es grotesca. Su papel, inexistente: es un figurante. Y, al tiempo, en ese papel de secundario que pasaba por allí, aparece el rey emérito, descolgado del tiempo y a destiempo, como en el cuadro de Antonio López de la familia real, entregado veinte años tarde y con otro soberano. 


\section{Preocupación ante las consecuencias del resultado}

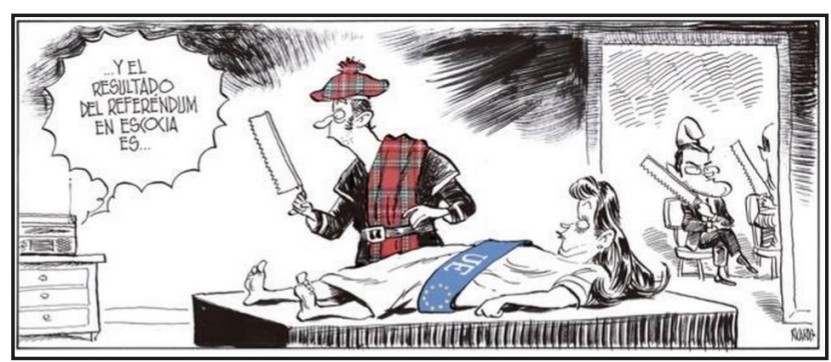

En esta línea de la influencia del referéndum de Escocia en España y en Europa, la preocupación ante las consecuencias del resultado es otro tema fundamental tratado por los diferentes humoristas de la prensa española. En El Mundo, el 19 de septiembre, Ricardo dibuja $^{19}$ a un escocés, ataviado con el tartán típico de los clanes, sujetando un serrucho y oyendo la radio mientras espera al resultado para desmembrar a una mujer que, postrada en una camilla, representa a la Unión Europea. En la sala de espera, Mas, con la barretina, aguarda su turno, con la sierra al brazo, para hacer una consulta separatista y dividir Europa. La crítica al nacionalismo, como desmembrador, es clara pero también es destacable el rol que adopta para los independentistas, así como la fragilidad e impotencia de la Unión Europea ante ellos.

Sin embargo, esa preocupación por el resultado del referéndum se volatiliza al día siguiente, al menos para los escoceses. Erlich, de El Pais, publica el 20 de septiembre de 2014, esta viñeta ${ }^{20}$ en la que se ve a dos escoceses, idénticos, bebiendo en armonía y tranquilidad tras conocer el 'no' a la independencia. La vida sigue en Escocia y ante esa tibieza a la hora del recuento cabe preguntarse si estos dos hombres, tanto el independentista como el centralista, sabían bien qué estaban votando y por qué votaban. La crítica al nacionalismo (tanto por irracional: son dos ciudadanos idénticos, como por sin sentido: se ha votado y ha salido el no y no pasa nada) es evidente.

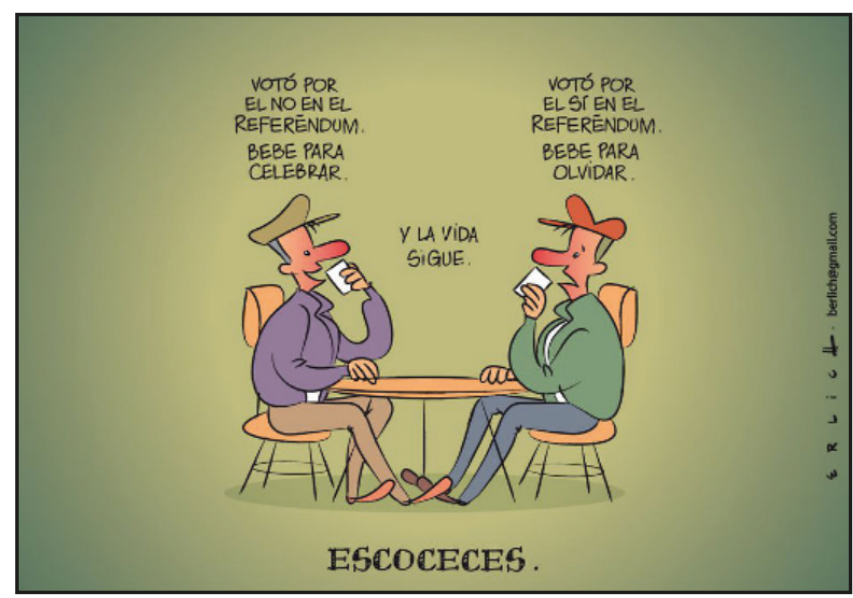

Por otro lado, la cuestión de qué sociedad deja una consulta tan polarizada queda planteada de manera evidente. El referéndum, tanto si hubiera logrado el sí como al haber obtenido un 'no', deja paso a una vida social en la que la población, realmente, no está muy dividida. Parece que los escoceses no pueden hacer mucho, salvo 
beber y, quizá, dejar que la burbuja explote por sí sola. En todo caso, la situación no es buena.

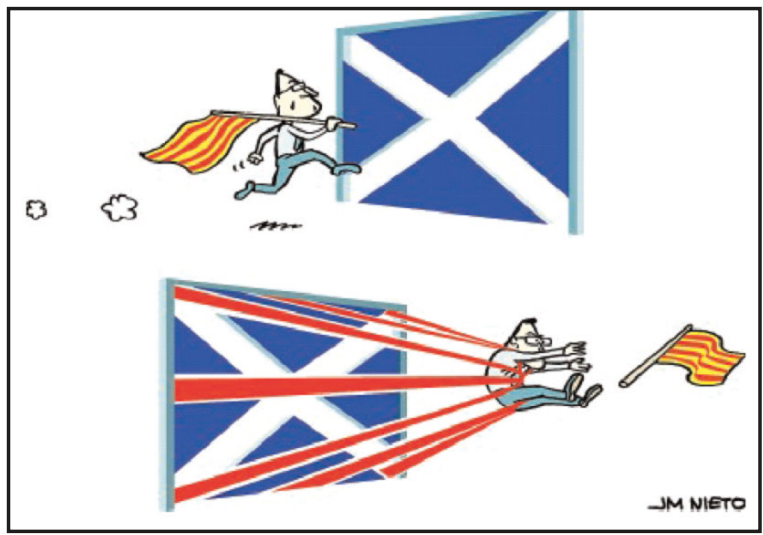

Sin embargo, frente al temple escocés -al menos, frente a ese conflicto suspendido-, la situación en España es completamente diferente. Los resultados del referéndum no han servido para reactivar la vida normal sino que han afectado tremendamente al devenir político. Nieto retrata $^{21}$ a Mas, en $A B C$ el 20 de septiembre de 2014, antes del referéndum escocés, con la bandera catalana de la mano pasando olímpicamente a través de la bandera escocesa que hace de puerta para el independentismo de Cataluña. En la parte de abajo, tras el resultado del referéndum y el rechazo a la separación, Mas aparece preso, como en un tirachinas, intentando llegar a la señera, que se le escapa abandonada, pues el 'no' del 18-S no ha ayudado a la independencia de Cataluña y no solo está Mas en la casilla de salida sino peor, preso en una situación difícil.

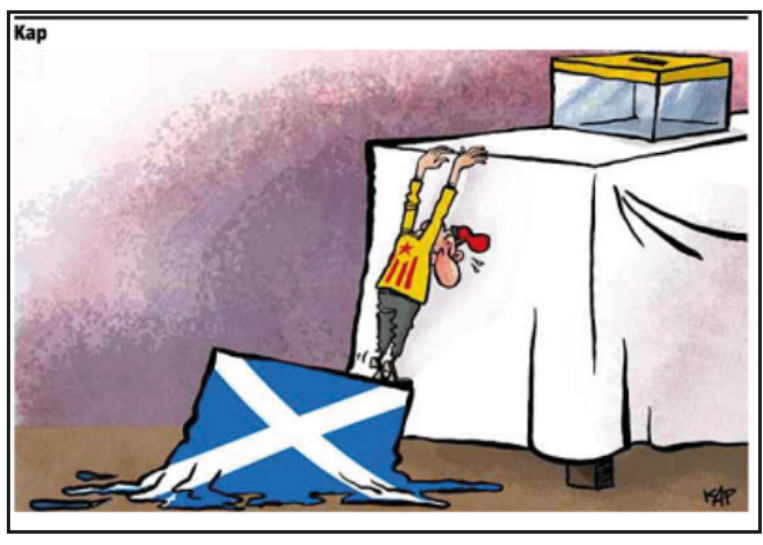

al impacto negativo de éste en su proceso secesionista.
Idéntica opinión tiene Kap en su viñeta ${ }^{22}$ publicada en $L a$ Vanguardia del 20 de septiembre de 2014. En ella se ve a un catalán, con la señera estampada en la camisa y la barretina, intentando auparse sobre las ruinas del independentismo escocés, cuya bandera está hecha jirones -metáfora del nacionalismo isleño-, para llegar a la urna electoral de la consulta catalana. Alude al golpe al independentismo catalán del 'no' escocés y

\section{La integración de los estados en democracia}

La insostenibilidad de los nacionalismos ha sido una de las cuestiones fundamentales tratadas por los dibujantes de los distintos periódicos. Ante una Europa en demo- 
cracia, y un estado pacífico y desarrollado, surge la cuestión de adónde llevará y qué supondrá el independentismo, tanto para los nacionalistas como para los centralistas, que ha prendido en el seno de ese mismo estado. Desde sus viñetas, los humoristas se han preguntado por el derecho a la autodeterminación de los pueblos. La cuestión de base es el nacionalismo y el independentismo pero no menos importante, y así lo tratan estos dibujantes, es el sentido democrático -o no- de este espíritu nacionalista y de su expresión en referéndums que buscan la independencia territorial y la autonomía política.

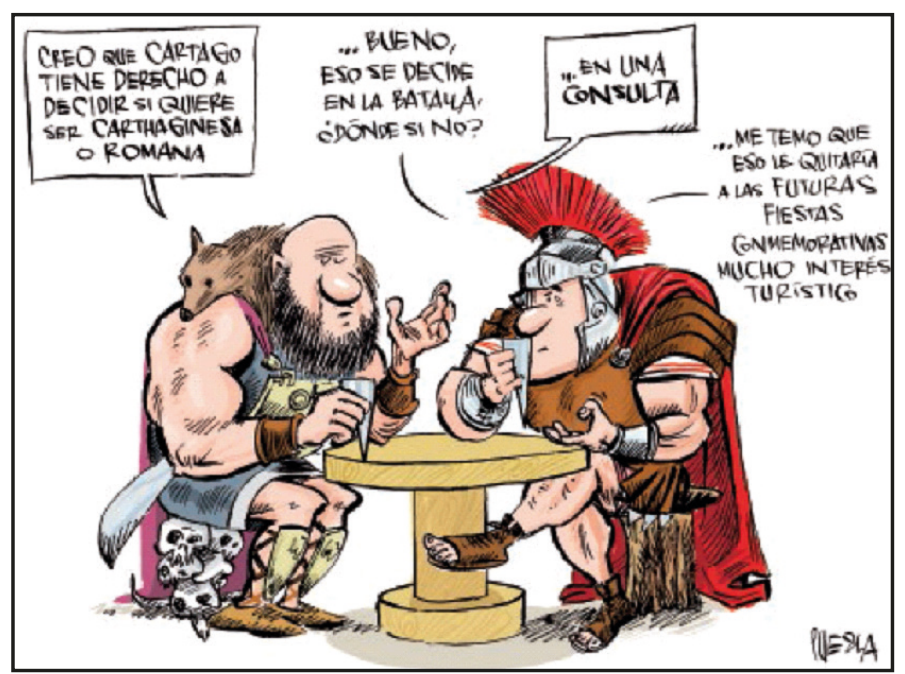

En $A B C$, Puebla se pregunta $^{23}$, el 21 de septiembre de 2014, qué independencia es la que se vota sin motivo alguno más allá que la del capricho surgido en una reunión social. El romano y el cartaginés beben, tranquilamente, cada uno con sus atributos propios (ataviado como un centurión, el romano) y en paz $\mathrm{y}$, en esa convivencia amistosa, el cartaginés (sentado sobre unas calaveras, con un aspecto mucho más fiero y pobre) le expone al centurión que cree que "Cartago tiene derecho a decidir si quiere ser carthaginesa o romana".

El romano señala que "eso se decide en la batalla" y remarca "¿dónde si no?", en referencia a las sucesivas victorias del Imperio Romano sobre Cartago, que acabó destruida, en las guerras púnicas. Ante este poderío militar de Roma, el cartaginés -que se sabe derrotado en un enfrentamiento- pide que sea "en una consulta" y el romano, triunfante, lo desestima. Al fin y al cabo, una independencia así lograda, traída por el viento, no tiene valor, no es un triunfo glorioso. Es decir, "quitaría mucho interés turístico a las fiestas".

Puebla alude, con esta viñeta, al sinsentido de la aspiración de celebrar una consulta secesionista, refiriéndose a la vacuidad de debatir sobre la legalidad de la misma para reforzarla o para desestimarla. La independencia debe conquistarse, no pretender ser obtenida a costa del fuerte por el débil. Cartago no puede pedir nada a Roma y, en todo caso, nada tiene que dar Roma, si no quiere, a los derrotados. Si Cartago quiere la independencia, tendrá que luchar -y contra un estado más fuerte, más próspero, más organizado- y, más aún, esta aspiración es absurda porque, en realidad, ambos beben tranquilamente y en paz. 


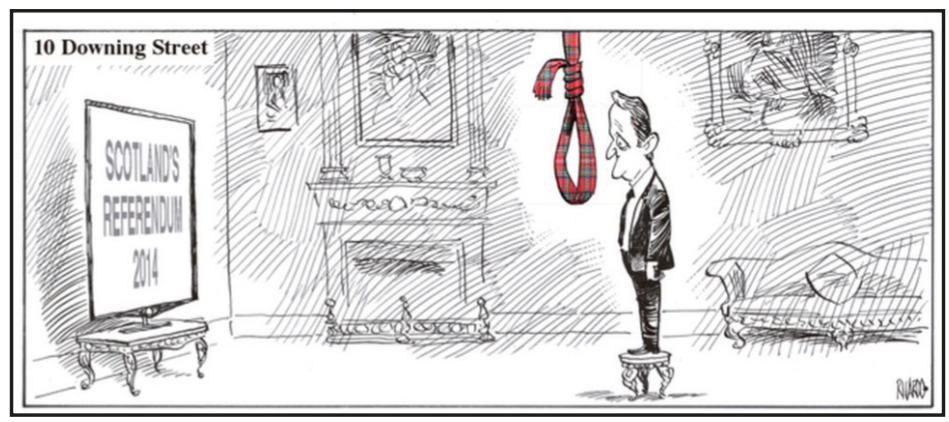

Esta reflexión sobre el sinsentido de permitir celebrar un referéndum secesionista queda claro en la viñeta ${ }^{24}$ de Ricardo, publicada en El Mundo el 18 de septiembre de 2014, en la que se ve a David Cameron de pie, en el 10 de Downing Street, sede del gobierno británico, ante una televisión en la que se alude al referéndum escocés de 2014. Está subido en un taburete y delante de él pende, a modo de horca, una bufanda de estampado escocés. Su cara transmite desolación. La idea de que el referéndum es una amenaza clara -la misma consulta, más allá del resultado- es evidente: la soga cuelga sobre su cabeza. La celebración de la consulta ha acabado con un principio de unidad, de beneficiosa amistad comercial y política, que ha presidido la política inglesa desde el siglo XVII a través de la Commonwealth con su consiguiente creación de una 'angloesfera' económico-política. El posible desmembramiento del Reino Unido, ejecutado a manos de Cameron, independientemente del resultado, es claro. La misma consulta es una amenaza al status quo histórico. Y, aún más problemático, ¿dónde se dirige esa independencia escocesa y qué ejemplo da para el resto del mundo?

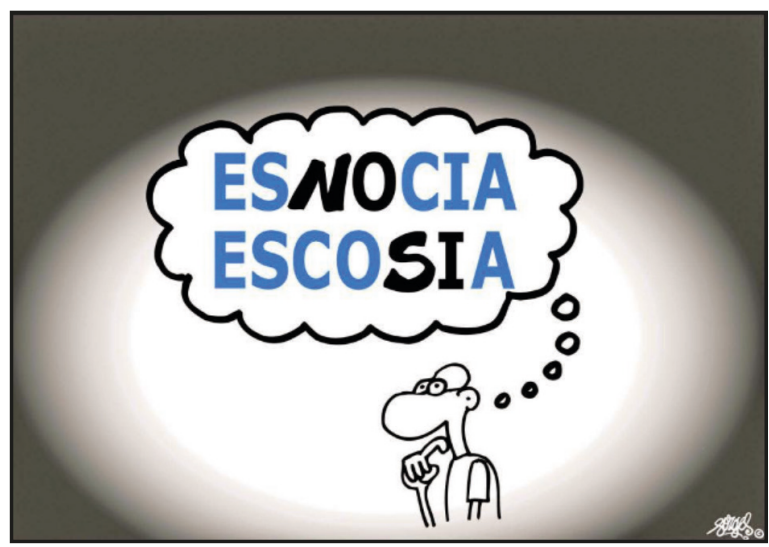

La falta de dirección, de sentido, la irracionalidad y frivolidad de la consulta es una preocupación de los diferentes dibujantes. Así, Forges ${ }^{25}$, en $\mathrm{El}$ País del 18 de septiembre de 2014, muestra a un ciudadano reflexionando sobre votar al 'sí' o al 'no' en Escocia a través de un juego de palabras. No parece haber más fondo que la mera elección de esa afirmación o negativa a la independencia y ello alude a la irresponsabilidad de decidir sobre un hecho tan trascendental y sin un programa de futuro ni un proyecto más allá del desbocado deseo nacionalista.

El cuestionamiento de este fervor nacionalista y de sus consecuencias es dibujado por Caín en La Razón el día 15 de septiembre de 2014. La viñeta ${ }^{26}$ muestra a un hombre que, a propósito de la vorágine independentista, llama a la mesura y, reflexionando, piensa que "tiene que haber una opción intermedia entre los que distorsionan 


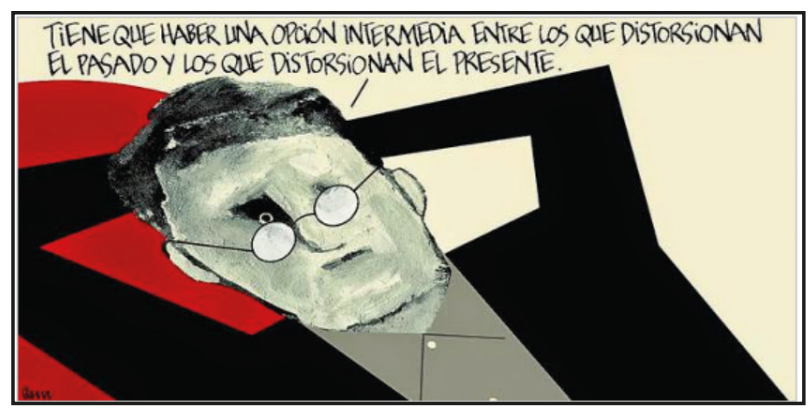

única opción viable para acabar con los problemas. el pasado y los que distorsionan el presente". De manera que este hombre pide una salida racional a la situación en que se vive tanto en España como en Europa a propósito del independentismo y cree que el separatismo $\mathrm{y}$, sobre todo, su bullicio, su manipulación, su falta de crítica y de un proyecto, no puede ser la

\section{El periódico de Cataluña: Una excepción en el tratamiento del 18-S}

El humorista gráfico de El Periódico de Cataluña se desmarca del resto en lo que respecta al tratamiento de la cuestión separatista escocesa. Así, este diario mantiene una postura a favor de la consulta, y lo hace criticando a la sociedad española por la falta de empatía que muestra hacia el separatismo catalán. Por ello, Ferreres ataca a la democracia que se lleva a cabo en España, entre otras cosas por no permitir referéndums para que ciertas sociedades tengan la libertad de decidir su futuro.

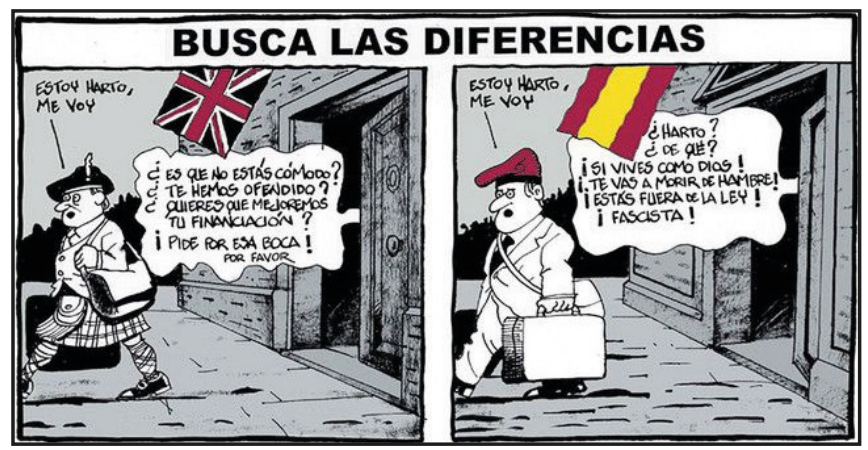

En esta viñeta ${ }^{27}$, Ferreres quiere mostrar las diferencias que hay entre España y Reino Unido ridiculizando a la sociedad española. En la primera imagen aparece un escocés que se quiere independizar de su país. Con talante democrático, una voz que procede de Gran Bretaña le pregunta que por qué se quiere ir, que si hay algo que pueda mejorar de su gestión (autocrítica) y se lo pide por favor (mostrando educación y saber estar).

Por el contrario, en la segunda imagen aparece un catalán diciendo "me voy", y una voz que representa a España -en vez de escuchándole, como en el caso anterior- criticándole, insultándole y anulando toda voluntad de diálogo. Utilizando como hilo argumental el nacionalismo, lo que el dibujante está queriendo mostrar es que España, como Estado-nación, no cuenta con los mismos valores democráticos que 
tienen lugar en otros países, como Gran Bretaña, y que el Estado central debe revisar su propia postura respecto a los nacionalismos.

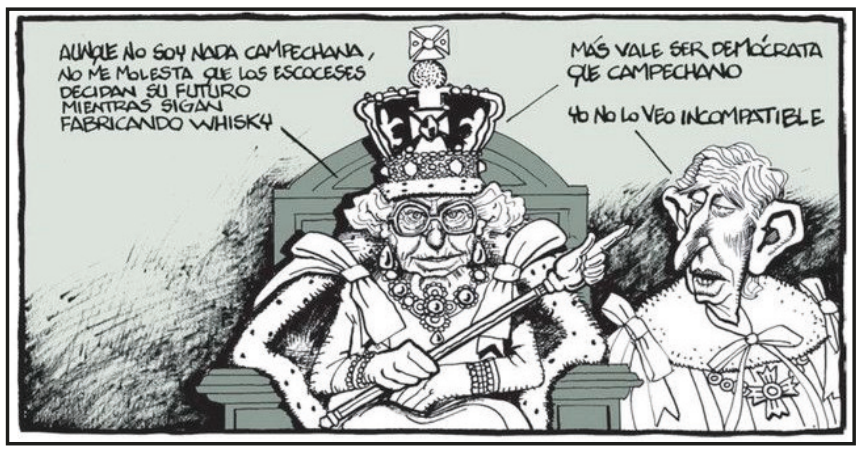

El día del referéndum, Ferreres ilustra ${ }^{28}$ a la reina de Inglaterra diciendo: "aunque no soy nada campechana, no me molesta que los escoceses decidan su futuro mientras sigan fabricando whisky", y añade -criticando a la Monarquía española-: "más vale ser demócrata que campechana". Lo que se interpreta de la viñeta de El Periódico es que, pese a la imagen conservadora que Isabel II pueda tener, en el fondo es más abierta que Juan Carlos I o Felipe VI, aunque parezcan más accesibles y 'campechanos'.

Hace una crítica a la Casa Real en particular y a la sociedad en general, ya que el trasfondo de la imagen vuelve a ser el mismo que en el ejemplo anterior: España representa una imagen progresista al exterior, y nos consideramos una sociedad moderna, pero en realidad no es así. Lo importante, para el dibujante, es poner en práctica lo que en teoría tenemos como forma de organización de Estado: un régimen democrático. También cuestionar el papel de la monarquía -de hecho, se planteó la cuestión de si Escocia iba a ser una república, a seguir siendo una monarquía y, de serlo, si iba a ser su soberana Isabel II-, tanto en Escocia como en España y Cataluña.

\section{Conclusiones}

Los resultados del estudio empírico realizado en esta investigación permiten corroborar, en línea con nuestra hipótesis de partida, que la fuerte cobertura que a través de sus viñetas realizaron El País, ABC, La Vanguardia, La Razón, El Mundo y El Periódico sobre el referéndum por la independencia de Escocia, así como la rotundidad con la que expresaron sus convicciones y argumentos, reflejaron una clara sintonía y relación argumental con el tema y los acontecimientos que por aquella época atravesaba España con Cataluña.

En primer lugar, es reseñable que, salvo El Periódico -que se posicionó abiertamente a favor del nacionalismo tanto escocés como catalán y en contra de las posturas centralistas españolas-, el resto de diarios, pese a su pluralidad ideológica manifiesta, repitieron los mismos argumentos e incluso iconografía para referirse al referéndum escocés y a sus consecuencias. Esto nos permite demostrar la existencia de una 'unanimidad' hacia la cuestión independentista por parte de las cabeceras 
de ámbito nacional, fruto de su reivindicación hacia la unidad del país y hacia la amenaza de los procesos separatistas.

Para justificar esta posición, El País, El Mundo, ABC, La Razón y La Vanguardia hicieron hincapié sobre dos grandes cuestiones: la crítica al fenómeno nacionalista y a las consecuencias que este acarrearía. En este sentido, es especialmente destacable la homogeneidad que mostraron estas cabeceras para expresar sus mensajes. Casi siempre hablando en general y rara vez en particular, los diarios expusieron su oposición al nacionalismo reprochándole su falta de bases ideológicas, la desinformación de sus seguidores y el sensacionalismo que generaba. En el caso escocés, llamó la atención, por ejemplo, el poco peso que concedieron a sus pretensiones separatistas, a las que coincidieron en calificar de absurdas y sin sentido, dándoles la misma veracidad que a Nessie, el fabuloso monstruo del Lago Ness.

En cuanto a la preocupación sobre las consecuencias del nacionalismo -tanto en Escocia, como en España y en Europa- estas se abordaron a través de varios ejes argumentales entre los que destacaron: la separación social, la situación democrática, la manipulación de los ciudadanos y el futuro del Viejo Continente, sobre todo en lo relativo a Cataluña. Así, no fue raro encontrar en los diarios alusiones a la 'corta vida' que esperaba a ambos procesos independentistas, bien mediante la representación de 'barcos a la deriva' o exhibiendo su rama económica más perjudicial.

Por otra parte, cabe señalar el poco protagonismo que se otorgó a los líderes de los procesos nacionalistas -sobre todo a Salmond que aparece una única vez-, y de las posiciones centralistas -Cameron en Reino Unido y Rajoy en España- en su representación gráfica. No así el de la iconografía, basada en un alto grado de conceptualismo y para el que la mayoría de los diarios utilizaron preferentemente los símbolos: como banderas y signos de identidad nacional -gaita, tartán, barretina...-. También fue destacable el peso del votante anónimo o de la masa ciudadana, vinculadas, en nuestra opinión, a la crítica al populismo, a su desinformación y a la falta de reflexión.

Por todo ello, consideramos que esta crítica feroz al nacionalismo escocés, así como la exposición repetida de sus consecuencias negativas o de los problemas vinculados a su extensión, fue tan alta por considerarla los periódicos una herramienta para tratar, enmascaradamente, la cuestión de Cataluña. El referéndum escocés se desveló así para la prensa española como un 'caballo de Troya' del proceso separatista catalán $\mathrm{y}$, en concreto, de la problemática del $9 \mathrm{~N}$.

A esta conclusión llegamos porque, de otro modo, un tema de política exterior, como es el encaje de Escocia en el Reino Unido -hay que considerar además que se trataba de un referéndum completamente legal y sin trabas ni conflictos entre el gobierno central británico y el local escocés-, no habría tenido tanta repercusión mediática; sobre todo si se tiene en cuenta que el humor gráfico es a menudo un género destinado a tratar asuntos de política nacional dentro de la prensa española.

Al respecto de estos hallazgos, consideramos que este estudio nos ha permitido mejorar la calidad de las investigaciones científicas sobre el humor gráfico que, como 
señalábamos al principio, a menudo carecen del rigor necesario. Este logro metodológico nos parece interesante pero creemos que la aportación de este artículo es la del análisis en profundidad de las viñetas de la prensa española como elementos editorialistas que reflejan la posición ideológica de los diferentes periódicos.

Así, consideramos que este trabajo abre una nueva línea de investigación en el campo de los estudios sobre prensa, en concreto, por atender un tema de gran actualidad e importancia. En España, la cuestión de la independencia de Cataluña sigue candente y, en septiembre de 2015 -un año después de la aprobación de la Ley de Consultas-, se ha desplegado de nuevo la maquinaria independentista (por ejemplo, de la coalición vinculada a Artur Mas de Junts Pel Si) en la campaña electoral de las elecciones autonómicas (adelantadas al 27-S). De ahí que se considere conveniente profundizar en el análisis de las 'opiniones publicadas' sobre las consultas nacionalistas en otros medios de comunicación, como la televisión, así como examinar la prensa inglesa y escocesa, tanto sobre el referéndum del 18-S como sobre la posible independencia catalana, para completar este trabajo.

\section{Referencias bibliográficas}

ABREU, C. (2000). "Periodismo iconográfico (V). Dibujo satírico, dibujo humorístico, chiste gráfico y caricatura", Revista Latina de Comunicación Social, 36. Disponible en: http://www.ull.es/publicaciones/latina/aa2000kjl/u36di/01abreu. htm. Consultado el: 17/05/2015.

BARRERO, M. (2008). "La controversia de las viñetas de Mahoma. Géneros, alcance y propaganda en la sátira gráfica", Mundaiz, 75, p. 1-45.

BOND, F. (1974). Introducción al periodismo. México: Limusa.

ECO, U. (2000). Entre mentira e ironía. Barcelona: Lumen.

GONZÁLEZ, J. (1996). "El texto tres registros y una dimensión", Trama y fondo: revista de cultura, 1, p. 3-32.

HERNÁNDEZ, M. L. (2001). "Humorismo gráfico en la prensa granadina de la Guerra Civil: López Sancho en Ideal". En: Dos décadas de cultura artística en el franquismo (1936-1956). Actas del Congreso, Universidad de Granada, p. 563-578.

KANT, I. (1990). Crítica de la razón pura. Madrid: Alianza Editorial.

LAGUNA, A. (2003). "El poder de la imagen y la imagen del poder: la trascendencia de la prensa satírica en la comunicación social", IC Revista Científica de Información y Comunicación, 1, p. 111-132.

LLERA, J. A. (2003).El humor verbal y visual de La Codorniz. Madrid: CSIC.

MARTÍNEZ, F. A.; GÓMEZ, J.L. \& BORDERÍA, E. (2008). "La recepción de las publicaciones satíricas: estudio de casos (La Traca y Gracia y Justicia)". En: Actas y memoria final: Congreso Internacional Fundacional AE-IC, Santiago de Compostela. 
MELÉNDEZ, N. (2005). El humor gráfico en el diario "El País" durante la transición política española (1976-1978). Tesis Doctoral, Universidad de Málaga.

MOREIRO, J., PRIETO, M. (2001). El humor en la Transición: diciembre de 1973-diciembre de 1978. Cinco años con mucha guasa. Madrid: Edaf.

NIETZSCHE, F. (1979). Humano, demasiado humano. Madrid: Edaf.

PEÑAMARÍN, C. (2002). "El humor gráfico del franquismo y la formación de un territorio translocal de identidad democrática", Cuadernos de Información y Comunicación, 7, p. 351-380.

RORTY, R. (1990). El Giro Lingüístico, Dificultades metafilosóficas de la filosofía lingüística. Barcelona: Paidós.

SEGADO, F. (2012). Un país de chiste: El humor gráfico durante la transición. Rialp: Madrid.

SEGADO, F. (2009). "Las puertas del campo: censura y coacción informativa durante la transición, reflejadas en el humor gráfico de la prensa diaria (1974-1977)", Anàlisi, 39, p. 17-34.

SEGADO, F. (2008). "Elenco de una nueva etapa: los protagonistas de la transición en las viñetas de la prensa diaria", Historia y Comunicación Social, 13, p. 167-178.

VV.AA (2013). La transición en tinta china. Ministerio de Cultura: Madrid.

\section{Notas}

1 Según los datos de la Oficina de Justificación de la Difusión para el periodo 2013-2014, se trata de los seis diarios más difundidos en España. Con esta muestra hemos intentado cubrir todo el abanico de actitudes políticas e ideológicas presentes en el territorio nacional.

2 EL ROTO (10 de septiembre de 2014). El País.

3 CAÍN (8 de septiembre de 2014). La Razón.

4 EL ROTO (19 de septiembre de 2014). El País.

5 ERLICH (21 de septiembre de 2014). El País.

6 CAÍN (20 de septiembre de 2014). La Razón.

NIETO, J.M (15 de septiembre de 2014). $A B C$.

8 EL ROTO (9 de septiembre de 2014). El País.

9 RAMÓN (12 de septiembre de 2014). El País.

${ }^{10}$ NIETO, J. M. (14 de septiembre de 2014). $A B C$.

${ }^{11}$ CAÍN (18 de septiembre de 2014). La Razón.

12 NIETO, J.M. (18 de septiembre de 2014). $A B C$.

13 IDÍGORAS y PACHI (20 de septiembre de 2014). El Mundo.

${ }^{14}$ GALLEGO \& REY (18 de septiembre de 2014). El Mundo.

${ }^{15}$ FORGES (17 de septiembre de 2014). El País.

16 PERIDIS (14 de septiembre de 2014). El País. 
17 BATLLORI, T. (19 de septiembre de 2014). La Vanguardia.

18 GALLEGO \& REY (20 de septiembre de 2014). El Mundo.

19 RICARDO (19 de septiembre de 2014). El Mundo.

20 ERLICH (20 de septiembre de 2014). El País.

${ }^{21}$ NIETO (20 de septiembre de 2014). $A B C$.

22 KAP (20 de septiembre de 2014). La Vanguardia.

${ }^{23}$ PUEBLA (21 de septiembre de 2014). ABC.

${ }^{24}$ RICARDO (18 de septiembre de 2014). El Mundo.

${ }^{25}$ FORGES (18 de septiembre de 2014). El Pais.

${ }^{26}$ CAIÍN (15 de septiembre de 2014). La Razón.

27 FERRERES (11 de septiembre de 2014). El Periódico.

${ }^{28}$ FERRERES (18 de septiembre de 2014). El Periódico.

* Esta investigación se ha realizado dentro de las actividades del Grupo de Investigación en Historia Reciente (GIRHE), financiado por la Universidad de Navarra 